\title{
BASIC HEMATOLOGICAL INDICES IN ADULT NUTRIA (Myocastor coypus M.) MALES
}

\author{
P. JELÍNEK \\ Department of Cattle, Horse and Sheep Husbandry, Faculty of Agronomy, \\ University of Agriculture, 66265 Brno
}

Received March 24, 1983

\begin{abstract}
Jelínek P.: Basic Hematological Indices in Adult Nutria (Myocastor coypus M.) Males. Acta vet. Brno, 53, 1948: 41-47.

The present study is aimed at estimating the basic hematological criteria (number of erythrocytes, hemoglobin concentration, hematocrit, mean corpuscular hemoglobin concentration (MCHC), mean corpuscular hemoglobin $(\mathrm{MCH})$, mean erythrocyte volume $(\mathrm{MCV})$, number of leukocytes and leukogram in clinically healthy nutria males 8-10 months of age.

The hematological values given above were estimated during the summer season in nutria bred on farms in brick pens with water reservoirs, from blood collected directly from the heart. The morphological characteristics of the individual blood constituents were documented using microphotographs and scanning electron microscopy.
\end{abstract}

Nutria, blood, morphology, blood cells.

Only a few authors have so far investigated the blood picture in nutria as compared with other species of fur animals kept on farms.

Schalm (1965 - quote Stankiewicz 1973), Wenzel (1974) and Hawkey (1975) give data on hematology of adult nutria but without any detailed specification as concerns the sex, breed, season and mode of breeding. Skalska and Baraǹska (1959) compared some blood indicators of nutria bred in different ways, either in pens with water reservoirs, using a system without water, or in larger enclosures where the animals were half free. Scheuring and Bratkowska (1976) dealt with the effect of age on the level of hematological values in nutria males and females obtaining, however, the necessary blood samples from the nostrils when the animals were killed. Buleca (1981) obtained samples from blood collected directly from the heart in 4 groups of animals ranging from 5 to 48 months of age.

The present study gives the basic hematological indicators in adult, clinically healthy nutria males from blood obtained directly from the heart.

\section{Material and Methods}

A total number of 22 male nutria of the standard breed, aged 240-300 days, were used for the investigations. The animals were kept in brick pens with water reservoirs, under conventional feeding consisting of a clover-grass mixture with grain supplement $(2 / 3$ of soaked barley and $1 / 3$ of wheat), waste bread was given occasionally.

Blood samples used for determination of the basic hematological values were collected directly from the heart into heparinized test-tubes and from each sample blood smears were prepared for the estimation of the differential leukocyteconnt.

Microphotographic documentation of the individual types of blood cells was done using a photomicroscope onto Agfachrome 504 professional. Electron microscopic pictures of erythrocytes were prepared on a scanning electron microscope Tesla BS- 300 under a $50^{\circ}$ inclination of the preparation after coating with carbon in a vacuum apparatus of the PP-400 type. 


\section{Results and Discussion}

The average values and total mathematical-statistical characteristics of the basic hematological values are given in Table 1 .

The number of erythrocytes in the individual cases ranged between $2.82 .10^{12} / 1$ and $5.74 .10^{12} / 1$, the average was $4.39 \cdot 10^{12} / 1$. The size of these blood cells ranged from $5 \mu \mathrm{m}$ to $8.8 \mu \mathrm{m}(\varnothing 7.4 \mu \mathrm{m})$. The shape of the erythrocytes can best be seen on electron microscopical pictures (Fig. 1,2) where the erythrocyte appears as

Table 1

General mathematical-statistical characteristics of the basic hematological values

\begin{tabular}{|c|c|c|c|c|}
\hline Basic values & $\bar{x}$ & $s$ & $S \bar{x}$ & $v$ \\
\hline $\begin{array}{l}\operatorname{Er}\left(10^{12} / 1\right) \\
\mathrm{Hb}(\mathrm{g} / \mathrm{dl}) \\
\mathrm{Hk}(1 / 1) \\
\mathrm{MCHC}(\mathrm{g} / \mathrm{dl}) \\
\mathrm{MCH}(\mathrm{pg}) \\
\mathrm{MCV}(\mathrm{f}) \\
\mathrm{Lc}\left(10^{9} / 1\right) \\
\text { Ne with rod-like nucleus }(\%) \\
\text { Ne with segmented nucleus } \\
\quad(\%) \\
\text { Eo (\%) } \\
\mathrm{Ba}(\%) \\
\mathrm{L}(\%) \\
\mathrm{Mo}\end{array}$ & $\begin{array}{r}4.39 \\
11.77 \\
0.43 \\
26.14 \\
27.18 \\
104.77 \\
9.41 \\
0.95 \\
\\
27.20 \\
4.5 \\
0.45 \\
64.95 \\
1.95\end{array}$ & $\begin{array}{r}0.73 \\
2.05 \\
0.06 \\
5.27 \\
4.61 \\
29.52 \\
3.30 \\
0.76 \\
\\
8.13 \\
2.28 \\
0.60 \\
8.25 \\
1.15\end{array}$ & $\begin{array}{l}0.17 \\
0.48 \\
0.02 \\
1.46 \\
1.09 \\
8.19 \\
0.76 \\
0.17 \\
\\
1.82 \\
0.51 \\
0.14 \\
1.84 \\
0.20\end{array}$ & $\begin{array}{r}16.63 \\
17.42 \\
13.95 \\
20.16 \\
16.96 \\
28.18 \\
35.07 \\
80.00 \\
\\
29.89 \\
50.60 \\
133.33 \\
12.70 \\
58.97\end{array}$ \\
\hline
\end{tabular}

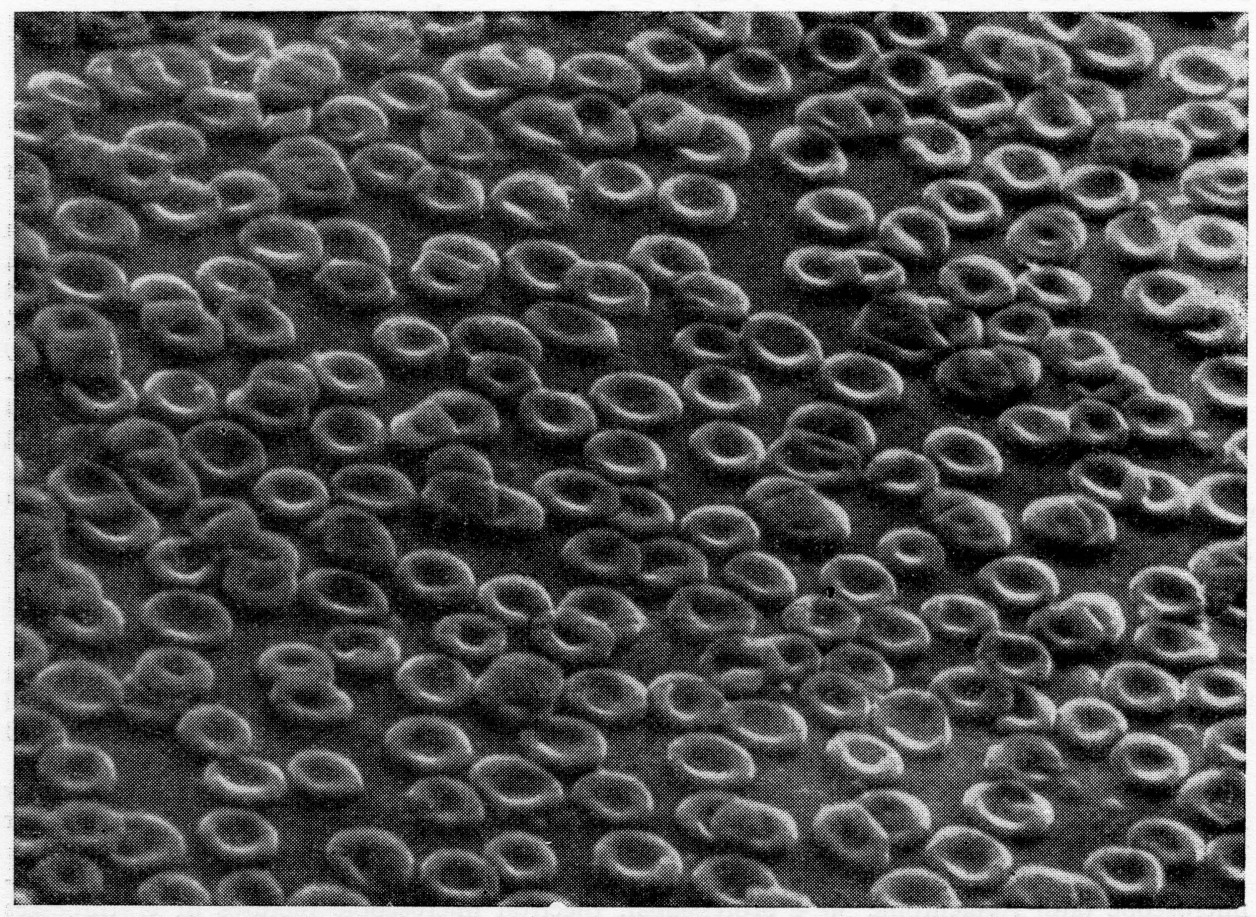

1. Scanning electron micrograph of red blood cells $(\times 1200)$ 


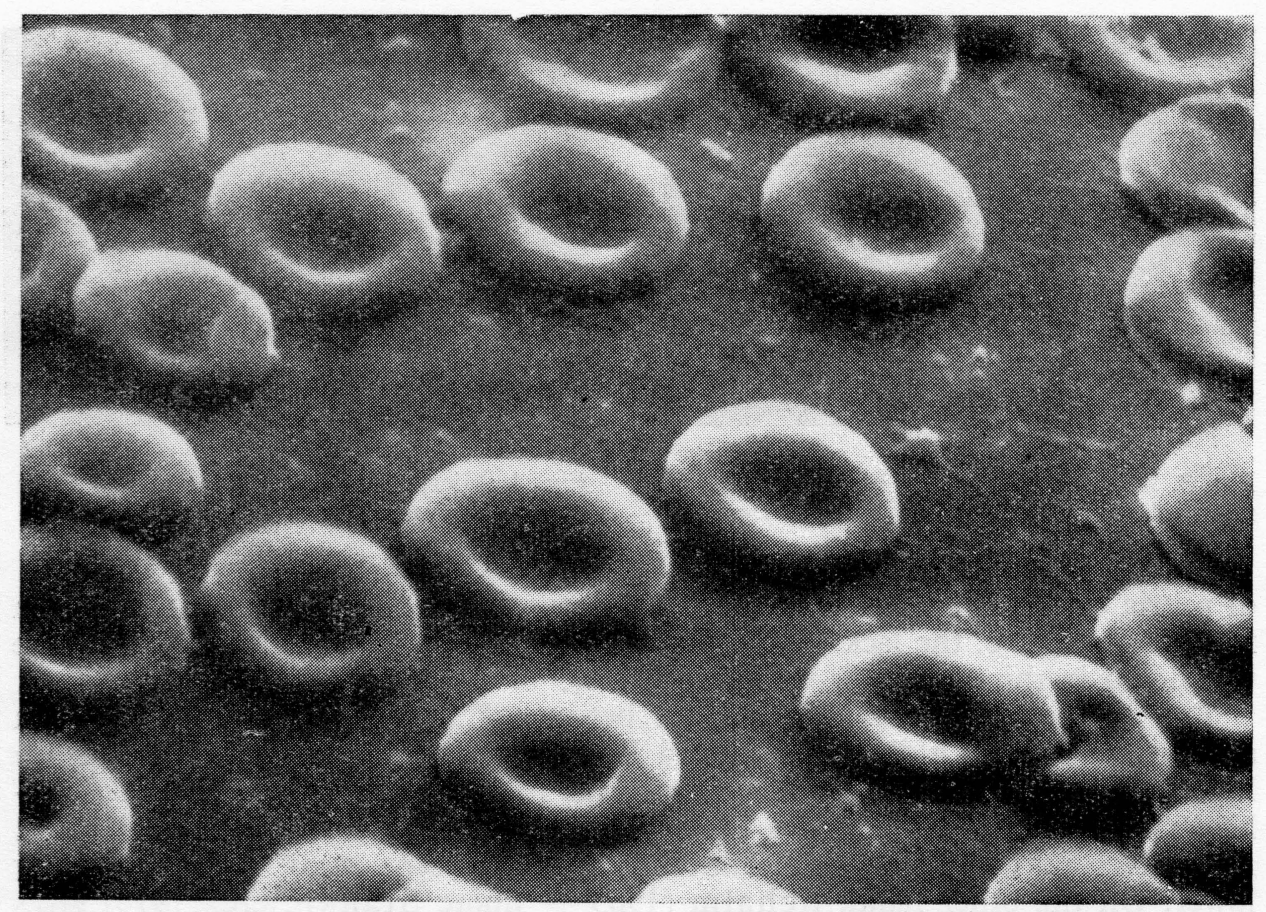

Fig. 2. Scanning electron micrograph of red blood cells $(\times 3600)$

a biconcave disc with no nucleus. The shape of the erythrocyte is evident also on the microphotographs.

If we compare findings given in the present study with data given by Skalska and Baranska (1959) who investigated the number of erythrocytes in nutria aged 6 months to 2 years under various husbandry systems, we find that the values in nutria males investigated in the present study in the given age span are somewhat higher. On the other hand, Schalm (1965 - quote Stankiewicz 1973) gives a higher value for the average erythrocyte count in adult males, i. e. $6.4 .10^{12} / 1$. Wenzel (1974) and Hawkey (1975) published approximately the same values for the total erythrocyte count $\left(4.1 .10^{12} / 1\right)$ in adult nutria (regardless of sex). Scheuring and Bratkowska (1976) investigated the effect of age on the number of erythrocytes in male nutria. They investigated nutria of 5 months to 4 years. As compared with the present results, these authors found a considerably lower total number of erythrocytes in all age groups, the average value in males and females being 3.16.1012/1 and 3.61 . 1012/1, resp. For the same age span, Buleca (1981) gives the average erythrocyte count as $4.02-4.29 \cdot 10^{12} / 1$.

When comparing this hematological constituent of the blood, the number of erythrocytes, with some other animal species, the average number of erythrocytes in nutria was found to be lower.

On the other hand, the mean size of erythrocytes was larger $(7.4 \mu \mathrm{m})$ than the values given e. g. by Novotný et al. (1966), Sova et al. (1978) in farm mammals, which corresponds with the well-known compensation mechanism. The shape 


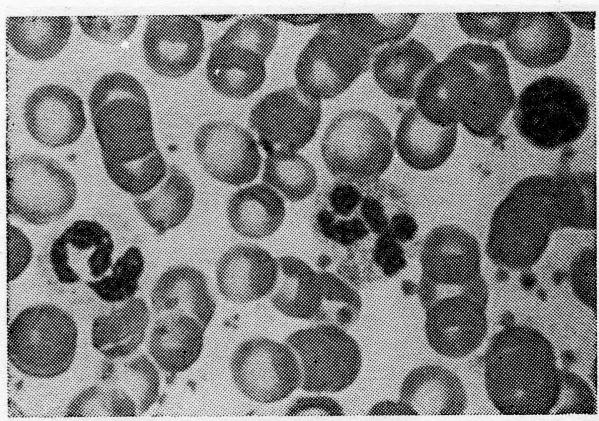

Fig. 3. Microphotograph of blood smear, neutrophil granulocytes and lymphocytes

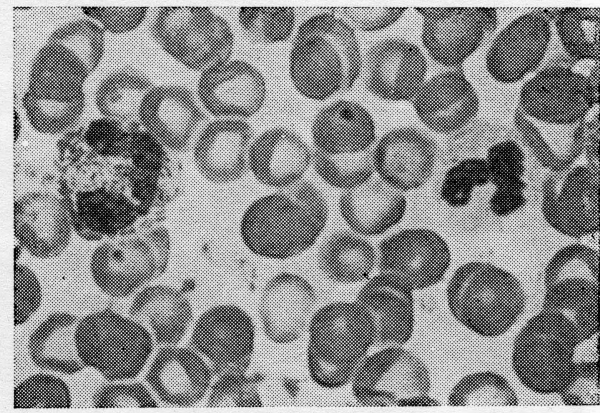

Fig. 4. Microphotograph of blood smear, eosinophile and neutrophil granulocytes

of nutria erythrocytes corresponds to the description of erythrocytes of common farm animals, i. e. the lack of nucleus and biconcave shape enlarging the surface was noted in this species as well (Fig. 1-6).

The amount of hemoglobin ranged between $7.37 \mathrm{~g} / \mathrm{dl}$ and $14.31 \mathrm{~g} / \mathrm{dl}$, with an average of $11.77 \mathrm{~g} / \mathrm{dl}$. Skalska and Barańska (1959) found that the average hemoglobin content in adult male nutria was $10.82 \mathrm{~g} / \mathrm{dl}$. Scheuring and Bratkowska (1976) gave the values $11.38 \mathrm{~g} / \mathrm{dl}$ and $11.0 \mathrm{~g} / \mathrm{dl}$ for males and females, respectively; with regard to the findings of the present study they are slightly lower. On the other hand, Schalm (1965 - quote Stankiewicz 1973) gives $13.6 \mathrm{~g} / \mathrm{dl}$ as the average amount of hemoglobin, Wenzel (1974) $12-14 \mathrm{~g} / \mathrm{dl}$, and Hawkey (1975) even $13.9 \mathrm{~g} / \mathrm{dl}$ in adult male nutria with an average number of $4.1 \cdot 10^{12} / 1$ erythrocytes.

Hematocrit values ranged between $0.391 / 1$ and $0.521 / 1$, with an average of 0.43 $1 / 1$ and mean level of variability $(v=13.95 \%)$. Scheuring and Bratkowska (1976), who evaluated the hematocrit level in nutria aged 5 months to 4 years, divided into 4 age groups, found that the hematocrit values increased from $0.361 / 1$ to $0.461 / 1$ in dependence on the time sequence. Hawkey (1975) gave a slightly higher hematocrit value $(0.481 / 2)$ for adult nutria. This author also noted a higher level of mean hemoglobin concentration $-29.0 \mathrm{~g} / \mathrm{dl}$; in the present investigation

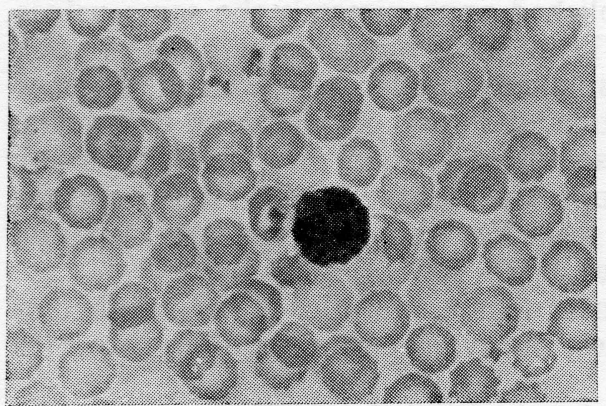

Fig. 5. Microscopic picture of blood with basophilic granulocyte

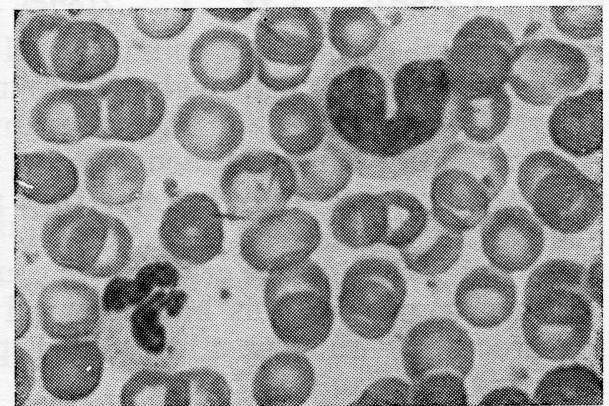

Fig. 6. Microphotograph of blood picture with monocyte and neutrophil granulocyte 
the average value was $26.14 \mathrm{~g} / \mathrm{dl}$. It cannot be excluded that such fine differences are of a methodical origin.

The average hemoglobin content in the erythrocyte was found to be $27.18 \mathrm{pg}$, with a variability within the investigated set evaluated by the variation coefficient $\mathrm{v}=16.96 \%$. For a direct comparison of the level of the mean hematocrit content in the nutria erythrocyte, only one datum can be used, published by Hawkey (1975). This author determined $34 \mathrm{pg}$ as the average hemoglobin content in the erythrocyte in the category of adult animals.

The last blood indicator which we used for the characterization of the red blood constituent in male nutria, was the mean erythrocyte volume. The individual volumes ranged from $74.91 \mathrm{fl}$ to $184.40 \mathrm{fl}$, with an average of $104.77 \mathrm{fl}$. The average value of the mean erythrocyte volume found by the author of the present study was slightly lower as compared with the finding of Hawkey (1975), i. e. $117.0 \mathrm{fl}$. Along with the well-known relationship, when the lower number of erythrocytes is compensated by changes in their size, the value of the mean erythrocyte volume can change also through the action of an unequal tension of $\mathrm{CO}_{2}$ in the erythrocytes, so that the blood cells in the arterial and venous blood show certain differences (Holub et al. 1969).

The total number of white blood cells is labile and considerably variable even under physiological conditions (Holub et al. 1969; Schalm et al. 1975; Sova et al. 1978). Also in the present study did their number show higher variations and differences among the individual animals as compared with the red blood picture indices. This fact also proved the level of variability evaluated by the variation coefficient. If we compare the average number of leukocytes given by Schalm (1965 - quote Stanckiewicz 1973), (Wenzel 1974) and Hawkey (1975) as $8.10^{9} / 1,9.8 .10^{9} / 1$ and $9.2 .10^{9} / 1$, respectively, our finding of $9.41 .10^{9} / 1$ in the corresponding category is slightly higher. Skalska and Barańska (1959) state that the number of leukocytes in adult male and female nutria is $12.10^{9} / 1$, Buleca (1981) gives a value ranging between 7.84 and $9.21 .10^{9} / 1$.

The percentage of neutrophile granulocytes with a segmented nucleus (Fig. 3) was $27.2 \%$, ranging between 15 and $46 \%$. The percentage of neutrophile granulocytes with a rod-like nucleus was $0.95 \%$. Scheuring and Bratkowska (1976) give a considerably higher percentage of neutrophils, i. e. $51.7 \%$, in the category of 8-month to 4-year-old nutria. Also Hawkey (1975) recorded a higher percentage as compared with the present findings, i. e. $54 \%$; Schalm $(1965-$ quote Stankiewicz 1973) even as much as $70.10 \%$. Results virtually the same as ours were published by Skalska and Barańska (1959) and Wenzel (1974) $28.40 \%$ and $29.60 \%$, respectively. These comparatively great differences are obviously caused by differences in the health condition of the animals investigated.

The size of the neutrophile granulocytes ranged between $9.6 \mu \mathrm{m}$ and $14.8 \mu \mathrm{m}$, the average value was $12.5 \mu \mathrm{m}$.

The relative percentage of neutrophile granulocytes with an unsegmented nucleus of the „rods" was, on the contrary, lower as compared with the findings of Skalska and Baraňska (1959) and Wenzel (1974), i. e. 5.3-6\% and $4.8 \%$, resp., which are values considerably higher also when compared with other species of farm animals.

The percentage of eosinophile granulocytes (Fig. 4) was $4.5 \%$ (the minimum was $1.0 \%$, the maximum $9.0 \%$ ). The size of these blood cells ranged between $10.0 \mu \mathrm{m}$ and $15.5 \mu \mathrm{m}$, with an average of $13.12 \mu \mathrm{m}$. The percentage of eosinophils given by Hawkey (1975) is quite coincident with values given in the present 
study (4\%); Skalska and Barańska (1959) recorded 4.2-6.5\% and Schalm (1965 - quote Stankiewicz 1973) $0.6-2.5 \%$. (Wenzel 1974) gives $1.4 \%$ for adult nutria and Scheuring and Bratkowska (1976) $1.1 \%$ in males and $1.6 \%$ in females. When comparing the present results with values given e. g. in cattle, sheep, goats, horses and pigs, they correspond with the range of physiological values in the given animal species (Schalm et al. 1975; Sova et al. 1978). As far as the size of the eosinophile granulocytes is concerned, the largest are the granulocytes in nutria, which corresponds with knowledge on other animal species as well.

The frequency of occurrence of the least represented blood constituent - basophilic granulocytes (Fig. 5) was very variable in males, which corresponds with general knowledge on the morphology and physiology of this cellular formation. Our present information about the relative proportion of these cells is in accordance with data obtained from other animals species under physiological conditions and when comparing with hemograms of nutria, the value $0.45 \%$ found in the present study corresponds with Wenzel's (1974) record; this author gives $0.4 \%$ of basophilic granulocytes. A higher relative number $(1.7 \%)$ was recorded by Schalm (1965 - quote Stankiewicz 1973), and other authors who dealt with basic hematology of nutria did not find this type of leukocytes in the blood of the animals investigated at all.

The most frequent and most stable category of leukocytes were lymphocytes with a mean value of $64.95 \%$. In adult nutria, however, Schalm (1965 quote Stankiewicz 1973) stated that neutrophile granulocytes were the most frequent type of white blood cells and the percentage of lymphocytes as only $25.9 \%$. Hawkey (1974) recorded somewhat more lymphocytes $(34 \%)$ in the blood of these animals. Scheuring and Bratkowska (1976) noticed a gradual decrease of the number of lymphocytes from $73.9 \%$ in nutria 5.5 months old to $43.3 \%$ in 8-month-old animals. The findings of Skalska and Barańska (1959) and Wenzel (1974) on the predominating lymphocytic constituent of the leukogram correspond with the results of the present study. These authors (Skalska and Barańska 1959) give the values of $51.6 \%-59.9 \%$ as the average amount of lymphocytes, Wenzel (1974) gives $60.4 \%$ of these elements.

In their size the lymphocytes (Fig. 3) rank among the smallest types of white blood cells of an average value of $8.2 \mu \mathrm{m}$ ranging from $5.8 \mu \mathrm{m}$ to $10.3 \mu \mathrm{m}$. When comparing the size of the lymphocytes of nutria with average parametres of other animal species, we find that the size of the small nutria lymphocytes is somewhat smaller; in their size they come the closest to the size of small lymphocytes in man and rabbits.

Monocytes, representing the second least occurring constituent of the differential count of white blood cells (Fig. 6), were found within the range of $1.0 \%$ to $4.0 \%$. Within this range also the average values were found; i. e. Schalm (1965 - quote Stankiewicz 1973) gives $2.8 \%$, Wenzel (1974) $2.1 \%$, S cheurin and Bratkowska (1976) $2.7 \%$, Hawkey (1975) gives a higher proportion $(8 \%)$. Under a more detailed comparison with leukograms of other adult farm animals, the findings of the present study, concerning the participation of monocytes, were slightly lower. When evaluating these literary differences the author is of the opinion that they are often caused by difficult es with exact diagnostics of monocytes in blood smears in relation to large lymphocytes; for an unambiguous standpoint it is very frequently necessary to use cytochemical methods.

The size of nutria monocytes ranged from $10.2 \mu \mathrm{m}$ to $16.3 \mu \mathrm{m}$ and the average value $14.1 \mu \mathrm{m}$ corresponds with the size of monocytes of other animal species. 


\section{Základní hematologické hodnoty u dospělých samců nutrií (Myocastor coypus M.)}

Práce byla zaměřena na stanovení základních hematologických kritérií (počet erytrocytů, koncentrace hemoglobinu, hematokrit, střední hemoglobinová koncentrace MCHC, střední obsah hemoglobinu v erytrocytu $M C H$, střední objem erytrocytu $\mathrm{MCV}$, počet leukocytů a leukogram) u klinicky zdravých samců nutrií ve věku od 8-10 měsíců.

Výše uvedené hematologické hodnoty byly stanoveny $\mathrm{v}$ průběhu letního období u nutrií chovaných faremním způsobem ve zděných kotcích $s$ vodními nádržemi z krve získané přímou srdeční punkcí. Morfologická charakteristika jednotlivých krevních elementů je dokumentována pomocí mikrofotografií a rastrovací elektronové mikroskopie.

\section{Основные гематологические величины у взрослых самцев нутрий (Myocastor coypus M.)}

Работа была направлена на определение основных гематологических критериев (численность эритроцитов, концентрация гемоглобина, гематокрит, средняя гемоглобиновая концентрация $\mathrm{MCHC}$, среднее содержание гемоглобина в эритроците $\mathrm{MCH}$, средний объем эритроцита $\mathrm{MCV}$, число лейкоцитов и лейкограмма) у клинически здоровых самцев нутрий в возрасте 8-10 месяцев.

Вышеприведенные гематологические величины были определены в течение летнего периода у нутрий, разводимых на ферме в каменных групповых клетках с бассейнами, из крови, полученной прямой пункцией сердца. Морфологическая характеристика отдельных әлеменгов крови приводится на микрофотографиях и снимках растровой электронной микроскопии.

\section{References}

BULECA, J.: Štúdium biologických vlastností nutrií. Ph. D. Thesis, Košice, 1981, 165p.

HAWKEY, C. M.: Comparative mammalian haematology. London, W. Heinemann Medical Books, 1975, 310 p.

HOLUB, A. et. al.: Fyziologie hospodářských zvířat. Praha SZN, 1969, 676 p.

NOVOTNÝ, E. - BÖHM, R. - GEISSEL, V. - HOLLMAN, J.: Veterinární histologie. Praha, SZN, 1966, 637 p.

SCHALM, O. W.: Veterinary Hematology. Philadelphia, 1965 (cit. Stankiewicz, W.: Hematologia weterynaryina. Warszawa, Państwowe Wydawnictwo Rolnicze i Leśne, 1973, 423 p.).

SCHEURING, W. - BRATKOWSKA, E.: Badanie wskaźników hematologicznych nutrii (Myocastor coypus, Molina 1782). Medycyna Weterynaryjna, 32, 1976: 239-241.

SKALSKA, H. - BARAŃSKA, H.: Obraz morfotyczny krwi obwodowej u nutrii chowanych systemem pólwolnym. Zeszyty naukowe Wyszej szkoly rolniczej we Wroclawiu, Zootechnika, 6, 1959, 21: 3-17.

SOVA, Z. et. al.: Biologické základy živočišné výroby. Praha, SZN, 1978, 580 p.

WENZEL, D. D.: Edelpelztiere. Deutscher Landwirtschaftsverlag, Berlin, 1974, 558 p. 